\title{
FRONTLINE RESPONSE TO HIGH IMPACT DOMESTIC VIOLENCE IN GERMANY
}

\author{
Stefanie Giljohann, ${ }^{1}$ Catharina Vogt ${ }^{2}$ \\ LisA SONDERN, ${ }^{3}$ PAULINA JUSZCZYK, ${ }^{3}$ JOACHIM KERSTEN ${ }^{2}$ \\ $\&$ BETTINA PFLEIDERER ${ }^{3}$ \\ ${ }^{1}$ Police Berlin, Berlin, Germany. \\ E-mail: gil@zedat.fu-berlin.de \\ ${ }^{2}$ German Police University, Criminology and Interdisciplinary Crime Prevention, \\ Münster, Germany. \\ E-mail: c.vogt@respectresearchgroup.org; joachim.kersten@t-online.de \\ ${ }^{3}$ Westfalian Wilhelm-University Münster, Faculty of Medicine, Münster, Germany. \\ E-Mail: lisa.sondern@wwu.de; paulina.juszczyk@wwu.de; pfleide@wwu.de
}

Abstract With a total of 141,792 incidents in 2019, domestic violence is a serious problem throughout Germany. The country chapter provides an overview of crime statistics and results from victim studies and a cost study. Concerning legislation, there have been two major waves improving victim protection in recent times, initiated by implementing the Act on Protection against Violence in 2002 and the ratification of the Istanbul Convention in 2018. An ongoing trend towards interagency cooperation and setting up coordination bodies can be noted in the social sector, also incorporating law enforcement agencies and medical institutions. After delineating the scope of responsibilities of front-line responders in the police, medical, and social sectors, the country chapter describes examples of good practices for interagency cooperation. The country chapter concludes with the main challenges to be anticipated in combatting domestic violence. The three main objectives identified are minimising unreported cases, expanding the scope of interventions, and improving victim protection in the short and medium-term. In the long term, the implementation of policies and standards will be vital to evaluate and improve prevention and protection measures to assure a high and nationwide comparable quality standard.

Keywords: domestic violence, Germany, interagency cooperation, victims, police 


\section{Country and legislation regarding domestic violence}

Germany is a federal parliamentary republic led by a chancellor. It is the European Union's most populous member state: Federal Statistical Office figures (2021) show that more than 83 million inhabitants live in the 16 constituent federal states (Länder). The largest city is Berlin, the German capital. Regrettably, domestic violence (DV) is a serious problem throughout the country.

In 2017, Germany ratified the Council of Europe Convention on Preventing and Combating Violence against Women and Domestic Violence (Council of Europe, 2011). As documented in the first German state report on implementation of the 'Istanbul Convention', considerable nationwide efforts have been made to improve the prevention, documentation and prosecution of crimes as well as to provide relevant professionals with guidelines for action, training and cooperation within the support sector (BMFSFJ, 2020). The Convention has also triggered legislative changes, such as the tightening up of the German criminal law on sexual offences in 2016 and the nationwide expansion of victim protection.

German legislation does not include a general legal definition of domestic violence nor does it provide a specific legislative framework. Instead, the applicable laws refer to criminal offences and are embedded in the national legislation in several fields of law like criminal and civil law, criminal procedure and administrative law as well as the Police Regulations (Polizeidientvorschriften) of the Länder.

Most offences committed in the course of domestic violence are investigated under the Criminal Code (Strafgesetzbuch/StGB) and prosecuted ex officio. These offences range from insult to offences against physical integrity, sexual selfdetermination, personal liberty and life. A significant milestone in women's protection came in 1997 when sexual coercion and rape within marriage became an offence ( $\$ 177$ StGB). In 2016, the legislation on sexual offences was further tightened: according to the principle "No means no", any sexual act against the apparent will of the victim, including touching them in a sexually explicit manner, is considered a criminal offence. Two more recent milestones in victim protection are legislation prohibiting stalking ( $\$ 238 \mathrm{StGB}$ ) in 2007 and its significant strengthening in 2017. With this latest change, stalking is punishable if the act is likely to seriously 
affect the victim's life, even if the victim does not give in to the pressure and/or does not change her/his life.

Apart from the StGB, the Act on Protection against Violence (Gewaltschutzgesetz/GewSchG) in particular plays a major role in victim protection. This act was introduced in 2002 as a national law in order to resolve the legal uncertainties of civil claims related to incidents of violence in the private sphere. GewSchG understands violence as all intentional and unlawful violations of the body, health or freedom of another person, regardless of whether the act takes place within a joint household or outside it. Within this concept of violence, the psychological aspect is also included "explicitly in the case of threats and unreasonable harassment, and indirectly when it has led to psychological or physical impairment to the health of another person" (BMFSFJ \& BMJV, 2019). The issue of a protection order lies within the jurisdiction of the district courts. GewSchG protects domestic violence victims primarily by facilitating the temporary allocation of a shared home to the victim ( $\$ 2$ GewSchG). Under GewSchG, housing allocations may be supplemented by additional protection orders; these are also regulated within GewSchG and include, for example, the prohibition on contacting or approaching the victim or approaching places usually frequented by the victim $(\$ 1$ GewSchG). The perpetrator's breach of such a judicial protection order constitutes a criminal offence.

The introduction of GewSchG expanded the police laws of the Länder by authorising the police to expel the perpetrator from a shared home in cases of the imminent escalation of violence. The expulsion order has a maximum duration of 10-14 days; an extension can be requested in court. Police laws differ slightly between the Länder with regard to this duration, the factual preconditions and further protective measures, such as contact, approaching and proximity bans. Breaching a police ban is not sanctioned under criminal law, but leads to stronger police measures, including taking the perpetrator into custody when the victim is at high risk of endangerment.

In cases of domestic violence involving a minor and/or a pregnant female, the law enforcement authority must inform the youth welfare office immediately, according to the Social Security Statute Book (Sozialgesetzbuch/SGB, §8a SGB VIII). This protection mandate of child and youth welfare must be fulfilled even if a minor may 
initially appear not to be a witness or victim of the violence. In case the minor's physical, mental or psychological best interests are endangered, the protective standards of the Civil Code apply (Bürgerliches Gesetzbuch/BGB, \$1666 BGB).

Finally, two important principles play an important role in victim protection and cooperation within the support network: the principle of legality and the principle of professional secrecy. The principle of legality means that German law enforcement authorities must intervene ex officio pursuant to the Code of Criminal Procedure (Strafprozessordnung/StPO). Police must investigate once sufficient indicators of offences have come to the attention of law enforcement agencies, regardless of the victim's intentions to report a crime $(\$ 152 \mathrm{StPO}$ in conjunction with $₫ 163$ StPO). Second, all professionals working in law enforcement, medical or social sectors are legally bound to exercise professional discretion ( $\$ 203 \mathrm{StGB}$ ), unless the person concerned has released them from this obligation or in cases of “justifiable need" ( $\$ 34 \mathrm{StGB})$. This requires a thorough consideration of whether the breach of confidentiality is a suitable and necessary means of averting an acute danger to life, limb or freedom which clearly goes beyond the patient's interest in confidentiality.

\section{Statistics on domestic violence in Germany}

\section{Police Crime Statistics}

Annually since 2015, the Federal Office of Criminal Investigation (Bundeskriminalamt) has published a special report on Police Crime Statistics (PCS) regarding "partner violence". However, the extent to which the PCS on partner violence relate to the actual crime rate and its development over time is difficult to assess because only a few representative, nationwide victimisation surveys on domestic violence have been conducted.

The most recent report for 2019 lists a total of 141,792 incidents of partner violence ${ }^{1}$ (Bundeskriminalamt, 2020), in line with the upward trend seen in the past few years. Without exception, the proportion of female victims was higher than that of men,

\footnotetext{
${ }^{1}$ The PCS count all registered offences (as opposed to victims) for which a police investigation was completed within the year. That is, if a person is repeatedly reported as a victim in the reporting period, they are several times included in the statistics.
} 
in total (81.0 \% were women) as well as in all offence categories. Most victims were recorded in cases of intentional minor bodily injury $(\mathrm{N}=86,812$ of whom $89 \%$ were women), followed by threats, stalking and coercion ( $N=32,477$, of whom $89 \%$ were women), and dangerous and grievous bodily harm (17,227, of whom $70 \%$ were women). The proportion of women was particularly high in cases of rape, sexual assault and coercion ( $98 \%$ women of $\mathrm{N}=3,086$ in total) and also quite high in cases of the deprivation of liberty ( $89 \%$ women of $\mathrm{N}=1,697$ in total). In total, 117 women and 32 men were victims of partner violence resulting in death in 2019.

In 2019, 118,176 suspects were reported for partner violence offences, including attempts ( $79.4 \%$ of them male). About half (50.5\%) the victims lived in the same household as the suspect. With regard to the relationship of the suspects to the victims $^{2}$, the status "former partnership" dominated with $39.0 \%$, followed by "spouse" and "registered civil partnership" with $35.0 \%$ and "unmarried partnership" with $29.7 \%$.

\section{Victimisation studies}

Schröttle and Müller (2004) conducted the first representative and nationwide victimisation survey on women's experiences of violence in Germany. For this purpose, a total of 10,264 women, aged 16 to 85 years, were interviewed between 2002 and 2004 about their experiences of violence, its consequences and their use of institutional help.

At least every fourth woman in the sample had experienced violence by an (ex)partner one or more times in the course of her life (Schröttle \& Müller, 2004). Two-thirds of these had encountered more than 1 violent situation, $24.3 \%$ more than 10 and $6.5 \%$ more than 40 incidents (Schröttle \& Ansorge, 2008).

Further, $23 \%$ of the women reported physical and $7 \%$ sexual violence by their (ex)partner (Schröttle \& Müller, 2004). The physical violence was classified as "very severe" in $37 \%$ of cases, including sexual violence (Schröttle \& Ansorge, 2008). The severity of psychological violence rose significantly with the severity of physical

\footnotetext{
2 The number in relationship status categories exceeds the actual number of suspects since the relationship status changed in several cases over the course of time and after further offences occurred.
} 
violence. Sexual violence was mainly "very severe" and was completed in $81 \%$ of the attempted cases.

(Ex)partners were by far the most frequent perpetrators (50.2\%) of physical and sexual violence in the overall sample, followed by other family members $(30.1 \%)$ and strangers (19.5\%) (Schröttle \& Müller, 2004). All forms of violence, including psychological violence, were committed to a greater degree by male perpetrators.

The study also addressed mutual physical violence in the last violent relationship, e.g. in the form of fighting back (Schröttle \& Müller, 2004): Two-thirds of the women physically fought back at least once, $36 \%$ "occasionally to frequently". Just under one-fifth of the women (19\%) stated they had initiated violence by physically attacking their partner at least once, for $4 \%$, this was the case "occasionally to frequently".

In order to shed light on the context of migration and violence, interviews with women of Turkish $(\mathrm{N}=368)$ and Eastern European origin $(\mathrm{N}=475)$, the two biggest migrant groups in Germany, were additionally analysed within the framework of this prevalence study (Schröttle \& Khelaifat, 2008). Both groups were identified as particularly vulnerable with regard to violence in partnerships (Table 1).

Table 1: Violence in the partnership. Criteria: All interviewed women up to the age of 75 who have once lived in a couple relationship (all) or, among this sample, those who refer to the recent partnership (recent)

(Schröttle \& Khelaifat, 2008)

\begin{tabular}{lccc}
\hline & Turkish & from CCCP & Germany \\
\hline physical/sexual violence (all) & $37 \%$ & $27 \%$ & $26 \%$ \\
\hline physical/sexual violence (recent) & $29 \%$ & $17 \%$ & $13 \%$ \\
\hline severe, frequent physical violence (recent) & $12 \%$ & $5 \%$ & $4 \%$ \\
\hline sexual violence (recent) & $6 \%$ & $3 \%$ & $1 \%$ \\
\hline psychological violence (all) & $20 \%$ & $14 \%$ & $7 \%$ \\
\hline
\end{tabular}

Besides the study of Schröttle and Müller (2004), no other representative victim survey has been conducted in Germany. Recent data on partner violence in Germany is retrievable from a European study that surveyed women ( $N=1,534$ in Germany) aged 18 to 74 years (FRA, 2014). This study showed a similarly high lifetime prevalence of partner violence in Germany as revealed in the study by Schröttle and Müller (2004): $22 \%$ of the women had experienced physical and/or sexual violence 
by (ex)partners since the age 15. During the 12-month period before the interview, this applied to $3 \%$ of the women. The lifetime prevalence of psychological violence was $50 \%$.

The most recent data on partner violence in Germany provides a snapshot of the exceptional situation during the first lockdown in spring 2020. In a representative online survey by Steinert and Ebert (2020), 3,800 women between 18 and 65 years of age were interviewed one month after the 1st lockdown (from 22 April to 8 May 2020) about the time during the pandemic. The results showed that women were exposed to different forms of emotional violence during the lockdown: $3.8 \%$ of them felt threatened by their partner, $2.2 \%$ were not allowed to leave their house without their partner's permission, and for $4.6 \%$ the partner regulated the woman's contacts with other people (including digital contacts). At least one physical assault at home had been experienced by $3.1 \%$ of the women, while $3.6 \%$ of the women had been forced to have sexual intercourse with their partner. The risk of experiencing physical violence increased with the stress factors involved and proved to be even higher for children than for their mothers.

Jungnitz, Puchert and Walter (2004) conducted a pilot study directed at partner violence involving men as victims. In this study, data concerning almost 200 men were included in the analysis. Almost every fourth man (22.6\%) had experienced violence by his current or last partner in the course of his life, $6.9 \%$ during the preceding 12 months. The men had been exposed to psychological violence, such as verbal attacks, humiliation and especially controlling behaviour much more frequently than physical violence during the course of their lives. Physical violence was generally not severe, but more a mild push (18\%), light slapping (7\%), biting, scratching, kicking as well as hard grabbing and pushing $(7 \%)$. Not a single man reported having been "beaten up". Men were also considerably less likely to have been affected by sexual violence ( $5 \%$ ). In these cases, they were more likely to be exposed to sexual harassment and, unlike women, they experienced coercive sexual encounters only in exceptional cases. About half the men affected by violence stated that they had never physically defended themselves during the violence. Two-thirds stated that they had never initiated physical violence. 


\section{Cost Study}

The first nationwide survey of the costs of domestic violence (Sacco, 2017) shows how far-reaching and large the financial impact of domestic violence is. The study considers "tangible" costs (e.g. for police, justice, counselling centres, shelters, healthcare), "indirectly tangible" costs (e.g. for loss of employment, unemployment, trauma follow-up costs for children) and "intangible costs", to which no direct but only a notional monetary value can be attributed (e.g. for life impairments due to fear, pain, illness or premature death). By adding tangible (EUR 1,043.8 billion) and indirect tangible costs (EUR 2,756.5 billion), the study arrives at total costs of at least EUR 3.8 billion per year. In addition, there is an estimated EUR 18 billion in "lifetime costs" caused by intangible costs.

\section{The response of the police, social and medical sectors to domestic violence}

In Germany, the main stakeholders active in preventing and intervening in cases of domestic violence are the police, the judiciary and institutions in the social and medical sectors. The following flowchart (Figure 1) gives an overview of the stakeholders' interconnected work while dealing with cases of domestic violence. 


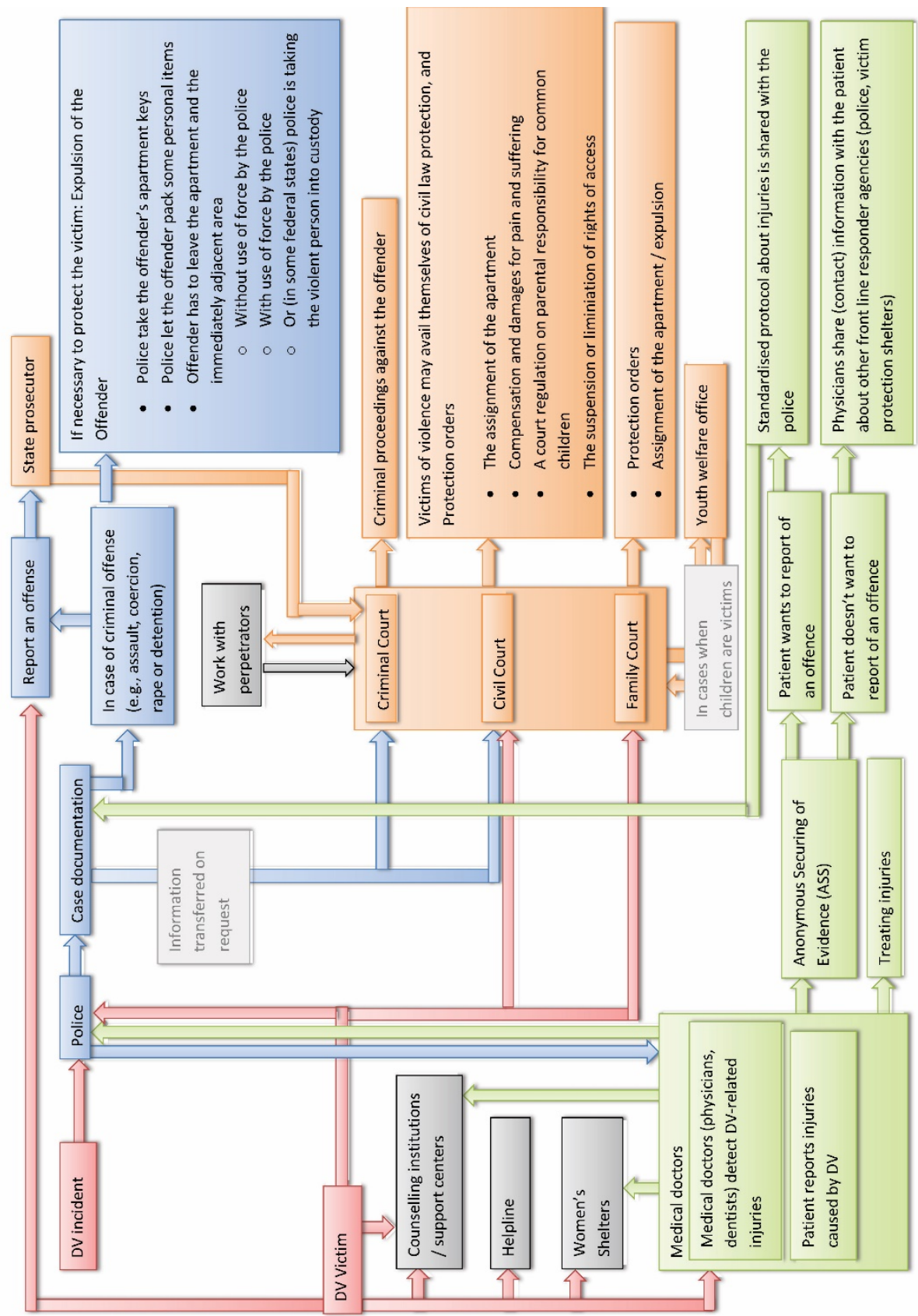

Figure 1: Overview of interventions in DV cases in Germany. The interventions of the main stakeholders active in this field are shown in different colours: the police (blue), judiciary (orange), social sector (grey) and medical sector (green). 
In cases involving a large number of cooperating organisations, there has been an ongoing trend to set up coordination bodies in the social sector, also incorporating law enforcement agencies and medical institutions. Two major waves of cooperation building in Germany can be identified in the past 20 years. The first was the result of the introduction of the Protection against Violence Act in 2001, which initiated or intensified cooperation in many places. Then came the implementation of the Istanbul Convention in 2018 and the explicit demand for inter-agency cooperation, risk assessment and case conferences, which triggered the wave we are currently experiencing. In Lower Saxony, for example, a total of 51 agencies that had already been working together for two decades formalised their cooperation by establishing the "Interdisciplinary Coordination Centre for Domestic Violence" (Interdisziplinäre Koordinierungsstelle Häusliche Gewalt) for the Braunschweig region in 2018. The pilot project "Combating Domestic Violence", which started in the Mannheim Police, Baden-Württemberg, in 2020 and the pilot project "Service Centre "pro-active" (Servicestelle «pro-aktiv»), which is being rolled out this year in Berlin, are good examples of forces joining together to implement scientificallybased high-risk assessment and interdisciplinary case conferences.

\section{The police sector}

The police are mainly reached in three ways: via police intervention after an emergency call and when victims voluntarily contact the police to file a complaint or seek a consultation. A risk assessment is to be carried out as soon as law enforcement agencies become involved. The degree of structure in the approach and the scientific soundness of the risk factors considered vary among the different agencies. Along with the case documentation, the risk assessment forms the basis for police interventions, which primarily aim to prevent (further) offences, reduce the risk of escalation and ensure prosecution. On this basis, the judiciary also grants necessary protective measures and sanctions offences.

With regard to the victim, the police take measures to avert danger, for instance by informing them about protective behaviours or bringing them to a safe place. Some police forces have committed themselves to the 'proactive' approach. This means they link victims and, in some places, also offenders with cooperating institutions in the support and counselling network in a timely manner. In high-risk cases, there are different approaches in the Länder for remaining in close contact with the victims. 
It is the declared aim that in the future interdisciplinary case conferences will be arranged nationwide in high-risk cases in order to be able to more effectively identify and exploit protection measures. In general, the principle applied is that restrictive measures, insofar as they are necessary, appropriate and proportionate, shall be directed primarily against the perpetrator. The main measures to be considered are an official warning, expulsion from the shared home, prohibition on approaching and contacting and, finally, detention (Giljohann \& Bendix-Kaden, 2020a, b). In some Länder, one can find additional measures like ankle bracelets in high-risk cases in Bavaria and North Rhine-Westphalia.

\section{The social sector}

Organisations of the social sector like NGOs, counselling services and support hotlines are a common entry point for victims of domestic violence. The overriding objective of the social sector is to reduce and prevent domestic violence, assist victims in establishing a life free of violence by addressing the structural causes of it, and support them in facing the consequences of their experiences. These organisations generally offer support by providing information, practical support and counselling. In addition, they are an important crossroads of the services of other agencies and sectors, including help in the labour and work market, legal and financial aid or medical care. The support is usually free of charge, being financed by the federal government, the Länder, associations and foundations, and it is often possible to access it anonymously.

This field also offers support for perpetrators, for instance via counselling hotlines or within domestic violence perpetrator programmes. The aim is to end violent behaviour. The courts can compel perpetrators to participate in such programmes. In this case, the counselling institution is obliged to provide feedback to the issuing authority on the progress and outcome of the measure (BMSFSJ, 2016). Standards for working with perpetrators are defined by the Federal Working Group on Perpetrators of Domestic Violence (Bundesarbeitsgemeinschaft Täterarbeit Häusliche Gewalt e.V.; BMSFSJ, 2008). 


\section{The medical sector}

The health effects of domestic violence are multifaceted (FRA, 2014; Schröttle, 2004) and of such a wide scope that medical professionals from all disciplines come into contact with its victims. The German Medical Association (Bundesärztekammer, 2015) emphasises that medical professionals are typically victims' first professional contact and thus hold outstanding responsibility in the recognition, intervention and prevention of domestic and sexual violence. Another task carried out by physicians is the confidential and court-proof securing of evidence.

\section{Good practice of co-operation between police, other frontline responder agencies, and relevant stakeholders in Germany}

To analyse good practice for multi-professional and inter-organisational cooperation networks within the IMPRODOVA framework, case studies were conducted on two well-established cooperation networks in the social sector in Germany (Bradley et al., 2020): the "Berlin Initiative against Violence towards Women" (Berliner Initiative gegen Gewalt an Frauen/BIG) and the "Hanover Intervention Programme against Domestic Violence" (Hannoversches Interventionsprogramm gegen Häusliche Gewalt/HAIP). BIG and HAIP share many similarities, which is not surprising since they were both developed in line with the Domestic Abuse Intervention Project (DAIP) from Minnesota, USA (Novak \& Galaway, 1983). In both cases, they aim to facilitate networked interventions, to (conceptually) improve victim protection, provide appropriate support and training to supporters as well as to influence the social and professional conditions to reduce incidences of domestic violence. These two cooperation bodies are the coordinating heart of their respective large multi-professional and inter-organisational networks, which consist of all professional stakeholders and societal forces relevant to their goals, such as the senate, police, justice system, counselling centres, women's shelters, child protection institutions and many more. BIG and HAIP both thrive on the fact that all actors are closely networked and precisely informed about their respective work, framework conditions and requirements. Thus, working in the permanent coordination units and temporary task groups is highly efficient. The start of HAIP was linked to a police order, which determined the basic process of the network: when the police receive information about a case of domestic violence, this is 
forwarded to the BISS centre, which then offers free counselling in a timely manner. HAIP offers this 'proactive approach' to victims as well as to offenders, while BIG and the Berlin Police have long had such a cooperation agreement for victims. When high-risk cases are identified within the HAIP network, case conferences are convened with the victim's consent to analyse the particular risk situation in depth and to jointly find effective protection strategies. Such a concept is also currently being developed in the BIG network. A far more detailed description of these two cooperation models can be found in the IMPRODOVA report on case studies (Bradley et al., 2020).

Many examples of successful inter-agency cooperation, ranging in size and orientation, can be found in Germany. A very small selection of these is mentioned below to illustrate the diversity of their content and structure. In the field of stalking prevention, the NGO "Stalking-KIT" (Crisis-Intervention-Team Stalking and Domestic Violence) in the city of Bremen is unique and well acknowledged. Operating since 2006, this cross-agency cooperation was developed by the police and the public prosecutor's office to provide stalking victims as well as perpetrators with professional help. Within this network, the timely interventions and their effects are reported back to the police, the public prosecutor's office, partners from victim support and offender control as well as other institutions or authorities relevant to the individual case.

Special mention should also be made in the medical field of S.I.G.N.A.L. e.V. in Berlin. For 20 years, this coordination and intervention programme has been committed to establishing sensitive and competent healthcare for victims of domestic and/or sexualised violence. It collaborates with all actors involved in the intervention chain against domestic and sexualised violence, with particularly close contacts with addiction counselling and care facilities, medical and nursing facilities, research institutions, forensic medicine institutes and child protection facilities. The most important goals include the systematic anchoring of intervention and prevention concepts in healthcare, the integration of the topic of domestic and sexualised violence into the education and training of healthcare professions along with the continuous refinement of intervention and prevention approaches. Other central concerns are the development of materials, public relations, knowledge transfer, the evaluation of intervention measures as well as the promotion of 
networking and professional exchange between the health sector and other actors involved in the intervention.

In this sense, S.I.G.N.A.L. e.V. has been the responsible agency for the "Round Table Berlin - Health Care for Domestic and Sexualised Violence", launched in 2018 by the Berlin government. The round table brings together 29 partners, particularly organisations from the health sector, but also from the psychosocial support system, child and youth welfare, violence prevention, law enforcement agencies, gender equality policy and science. In a joint cooperation declaration, the members agreed to embed the WHO guidelines for dealing with violence in relationships and sexual violence (WHO, 2013) in Berlin's healthcare system and thus to implement the essential health-related requirements of the 'Istanbul Convention'.

As part of the federal government's "Action Programme against Violence against Women", another influential round table was launched in the same year. It draws together representatives of the federal government, of all 16 Länder and the most important municipalities to expand and financially secure the work of women's shelters, outpatient help and care facilities. Legal solutions for a nationwide uniform procedure in emergencies are being sought, e.g. in the form of paying the costs for accommodation in a women's shelter or a legal right to protection and counselling.

\section{Main challenges and issues to be anticipated while managing domestic violence in Germany}

The extensive research and the interviews with first responders in domestic violence cases conducted as part of IMPRODOVA revealed short-, medium- and long-term challenges, some of which we address in this concluding section.

\section{Short- and medium-term challenges: Prevention and protection matter}

Three important objectives are identified among the main challenges in domestic violence management: minimising unreported cases; expanding the scope of interventions; and improving victim protection. 


\section{- Minimising unreported cases}

The sustainable prevention of (further) violence and victim protection depend on victims being able to access the support system. Thus, whatever barriers exist that prevent victims, bystanders and/or perpetrators from reporting domestic violence to first responders or making contact with support networks must be lowered.

To lower this threshold, it is essential that those involved have a comprehensive view of the phenomenon in all of its various manifestations, together with an attitude of gender equality and intolerance of any form of violence. For all parties, be they victims, bystanders or perpetrators, this means they must have developed a sense of when a red line has been crossed in order that they seek help before a domestic violence incident occurs or escalates. In Germany, far more education, sensitisation and empowerment is needed to increase the number of calls made for help.

At the same time, requesting help and reporting a case requires that services be available and accessible. While both criteria are often met in metropolitan areas, rural areas often lack such infrastructure. Although there is a 24/7 nationwide hotline in Germany, face-to-face contact and a somewhat longer period of support than can be provided by a hotline are often indispensable for victims. As a result of the Covid 19 pandemic, many support services now offer digital counselling and it is desirable that this extended accessibility be maintained in the future. There are also various examples of an overall lack of services and/or funding for certain support forms in Germany, such as psychotherapy, trauma- and violence-informed medical care, counselling for perpetrators, services for male victims and women's shelters.

Beyond this, the support network needs to be trusted to provide help when needed, and unfortunately this trust is currently not yet strong in Germany. According to an EU-wide survey on intimate partner violence (FRA, 2014), $14 \%$ of respondents stated they did not believe the social support system could offer them support. Respondents also stated that they believed the police would not act $(14 \%)$ or could not act $(14 \%)$, that they would not be believed $(9 \%)$, and that the fear of the perpetrator was too great $(14 \%)$. Accordingly, it remains an important task to communicate more clearly the seriousness with which the support network takes the injustice experienced by victims and that domestic violence will not be tolerated, in addition to the forms of support offered. 


\section{- Expanding the scope of interventions}

In order to support more victims of domestic violence, they must be recognised even if they do not reveal themselves as such. Correctly identifying cases of domestic violence requires frontline responders to be aware that they are seeing victims each and every day. This holds true for the police and frontline responders in the social sector, but also for medical professionals, who ought to be more aware that even among their patients there are victims of domestic violence. After all, the medical sector is the sector most frequently approached by domestic violence victims (FRA, 2014): $20 \%$ of the victims stated they had visited a doctor, health centre or other healthcare facilities, while $9 \%$ stated they had visited a hospital (vs. $11 \%$ approaching the police and $5 \%$ social services/victim protection institutions). However, victims rarely talk to doctors about their experiences of violence (Grass, Mützel \& Preuss, 2014) and thus doctors need to become better at detecting victims. Even though doctors generally do not ask patients about possible experiences of violence when they have been injured, it may be assumed that there is a high level of social acceptance in Germany in this regard: $83 \%$ of respondents in the FRA study stated that such a routine question was acceptable to them (FRA, 2014).

Within the framework of a federal pilot project with medical professionals, the majority of participants stated at the project's beginning that they had no routine for dealing with potential victims of domestic violence (Steffens, Janz \& Stolte, 2015). Two-thirds of them admitted that they did not feel sufficiently informed to be able to appropriately deal with potential victims. Beyond the insecurity in dealing with victims, a lack of knowledge about available support services was also revealed. More than $70 \%$ of the respondents had not yet participated in any training on the topic. Given that this topic is not part of the curriculum in medical schools either, there is an urgent need for action to integrate it into their curriculums and to create sufficient certified training opportunities to ensure that domestic violence cases are identified and referred to the support system. 


\section{- Improving victim protection}

In the field of victim protection, challenges and opportunities for improvement were identified with respect to the process of securing evidence, case documentation, risk assessment, protection measures and interagency cooperation, as explained in the following paragraphs.

\section{Securing evidence}

The more the influencing factors are assessed by the frontline responders, the more effective the victim protection becomes. The initial step in this direction is to secure evidence. Here, the police and the medical sector play an important role. However, physicians and hospitals do not inform victims sufficiently about the possibility of securing evidence (S.I.G.N.A.L., 2018). While German police officers are well trained in the securing of evidence, most professionals in the medical sector are not. To establish a high standard of documentation in the medical sector, it is important to raise awareness of training and of the well-developed materials available to many medical disciplines (e.g. the materials provided by S.I.G.N.A.L. (2020), based on the WHO's guidelines). Further, greater transparency is needed about how different hospitals, organisations and medical practices deal with securing evidence and the anonymous securing of evidence in particular.

\section{Documenting cases}

The second step in victim protection involves case documentation. Documentation and case processing in the police is IT-based and thus strongly standardised. After the first police contact, in some police organisations the case processing is taken over by officers specialised in domestic violence. Case completion is then checked by a supervisor, ensuring regular quality control of both the documentation and the case processing. In contrast, and although some positive exceptions exist, systematic case documentation seems rare in the social sector and too little is known about how it is done in the medical sector to generalise. Opportunities to support victims in possible court proceedings may be missed here since it is possible that victims release frontline responders from their duty of confidentiality. In these cases, good documentation for a witness statement is inevitable. 


\section{Assessing the risk}

Well-secured evidence and documented cases provide a solid basis for an accurate risk assessment. German police forces are at very different stages of risk assessment development, ranging from experts using a standardised approach or even a validated risk assessment tool (e.g. Danger Assessment, Campbell, Webster \& Glass, 2009) to officers trained in using generally structured approaches or checklists, to risk assessment mainly based on expertise, common sense and intuition. It is to be hoped that a more comparable approach with minimum standards will be established nationwide. In the social sector, risk assessment seems to be predominantly woven into the analysis of the individual problem and the search for solutions during counselling. Too little is known about risk assessment in the German medical sector to allow generalisation (Hera \& Szego, 2020).

\section{Initiating protective measures}

The outcome of the risk assessment determines the choice of protective measures. Enforcing repressive measures is the sole responsibility of the German police. In addition, consulting victims on security measures is a standard procedure. It is desirable that the pro-active approach applied by many police forces would likewise become a common practice across the country, especially if it links not only victims but also perpetrators to the support network. However, the latter are still underrepresented in the support network in many regions in Germany and their resources are generally quite limited. With regard to the social sector, it seems well established that consultations on self-security are carried out very thoroughly but, once again, too little is known about the medical sector to generalise.

\section{Cooperating to better support victims}

To comprehensively support and protect victims of domestic violence, frontline responders and other professionals working with victims must cooperate. Although the ratification of the Istanbul Convention entails the obligation to promote and strengthen inter-agency cooperation and while some best practice examples exist that show how all sides benefit from the interaction of various stakeholders (Bradley et al., 2020), the situation in Germany calls for improvement. In some cases, the stipulated exchange of information between institutions is still not efficient enough. 
For example, the late transmission of violence protection decrees to the police could endanger not only the victim but also the officers on duty as they are then unaware of possibly relevant information about the threat posed by the perpetrator. In particular, the medical sector, as an important reference for domestic violence victims, should be better integrated into the support network. Moreover, the lack of cooperation leaves especially high-risk cases far too isolated in potentially lifethreatening situations. Case conferences, which are already in place in some Länder, urgently need to be rolled out nationwide when victims are at high risk.

\section{Long-term challenges: Policies matter}

Organisationally and educationally speaking, the police have quite homogeneous structures that for other groups of frontline responders in Germany do not (yet) exist. The underlying national legal framework and the police regulations provided by the Länder define how domestic violence is to be dealt with. This transparent approach permits the strengths and weaknesses to be clearly delineated.

In contrast, the medical and social sectors consist of very diverse organisations with very different ideologies, principles and organisational cultures. Training still holds a subordinate role, at least in the medical field, and this should change to make violence-informed treatment the standard of medical care. Regulations with regard to dealing with domestic violence victims are non-existent or merely recommendations, and an evaluation of the situation is not taking place. This particularly includes the challenge of identifying cases of domestic violence among patients and the question of how to best deal with them in the context of the healthcare system.

In the long term, the implementation of policies and standards will be vital for evaluating and improving prevention and protection measures in domestic violence cases to assure the quality standard this important work needs to have throughout the country. Starting from the Istanbul Convention, policies for both the medical and social sectors could be developed with respect to dealing with victims of domestic violence and, in the second step, be aligned with police regulations in order to build a cooperative approach (Vogt, 2020). Further, the WHO's guidelines offer important reference points for establishing minimum standards, such as that professionals working with victims of domestic violence should be trained on this 
topic, that standard procedures are established in which confidentiality is guaranteed, privacy is maintained, and that referrals to further services and court-proof documentation of injuries and traces are ensured.

\section{References}

BMSFSJ. (2008). Standards und Empfeblungen für die Arbeit mit männlichen Tätern im Rabmen von interinstitutionellen Kooperationsbündnissen gegen bäusliche Gewalt der Bundesarbeitsgemeinschaft Täterarbeit Häusliche Gewalt e.V. https://www.bagtaeterarbeit.de/images/pdf/Standards_THG_Langfassung.pdf

BMFSFJ. (2016). Gewalt gegen Frauen: Täterarbeit. https://www.bmfsfj.de/bmfsfj/themen/gleichstellung/frauen-vor-gewaltschuetzen/haeusliche-gewalt/gewalt-gegen-frauen-taeterarbeit/gewalt-gegen-frauen-taeterarbeit/80700

BMFSFJ. (2020). Report submitted by Germany pursuant to Article 68, paragraph 1 of the Council of Europe Convention on preventing and combating violence against women and domestic violence (Baseline Report). https://rm.coe.int/state-report-from-germany/pdfa/16809f59c6

BMFSFJ \& BMJV. (2019). Greater Protection in Cases of Domestic Violence. Information on the Act on Protection Against Violence.

https://www.bmjv.de/SharedDocs/Downloads/DE/Service/Formulare/Mehr_Schutz_bei _haeuslicher_Gewalt_ENG.pdf?_blob=publicationFile\&v $=7$

Bundesärztekammer. (2015). Beschlussprotokoll. Frankfurt am Main, 12. bis 15. Mai 2015. https://www.bundesaerztekammer.de/fileadmin/user_upload/downloads/pdfOrdner/118._DAET/118DAETBeschlussprotokoll20150515.pdf

Bundeskriminalamt. (2020). Partnerschaftsgewalt Kriminalstatistische Auswertung - Berichtsjahr 2019. https://www.bka.de/DE/AktuelleInformationen/StatistikenLagebilder/Lagebilder/Partners chaftsgewalt/partnerschaftsgewalt_node.html

Bundesministerium für Familie, Senioren, Frauen und Jugend. (2005). Lebenssituation, Sicherheit und Gesundheit von Frauen in Deutschland. Eine repräsentative Untersuchung zur Gewalt gegen Frauen in Deutschland. https://www.bmfsfj.de/bmfsfj/studie--lebenssituation--sicherheit-undgesundheit-von-frauen-in-deutschland/80694.

Bundesministerium für Familie, Senioren, Frauen und Jugend. (2008). Gesundheit-Gewalt-Migration: Eine vergleichende Sekundäranalyse zur gesundheitlichen und sozialen Situation und Gewaltbetroffenheit von Frauen mit und ohne Migrationshintergrund in Deutschland.

https://www.bmfsfj.de/resource/blob/93964/588d6d5da075d2803f8696dfbbe3d35c/gesun dheit-gewalt-migration-langfassung-studie-data.pdf

Bundesministerium für Familie, Senioren, Frauen und Jugend. (2008a). Gewalt gegen Frauen in Paarbeziehungen - Eine sekundäranalytische Auswertung zur Differenzierung von Schweregraden, Mustern, Risikofaktoren und Unterstützung nach erlebter Gewalt. https://www.bmfsfj.de/blob/93968/f832e76ee67a623b4d0cdfd3ea952897/gewaltpaarbeziehung-langfassung-data.pdf

Campbell, J. C., Webster, D.W. \& Glass, N. (2009). The danger assessment: validation of a lethality risk assessment instrument for intimate partner femicide. Journal of Interpersonal Violence, 24(4), 653 - 674. doi: 10.1177/0886260508317180

Council of Europe. (2014). Council of Europe Convention on preventing and combating violence against women and domestic violence. https://wcd.coe.int/ ViewDoc.jsp?id=1772191\&Site $=$ CM\&BackColorInternet $=$ C3C3C3\&BackColorIntranet $=$ EDB021 \&BackColorLogged $=$ F5D 383 
FRA. (2014). Violence Against Women: An EU-wide Survey: Main Results (Dignity). https://fra.europa.eu/sites/default/files/fra_uploads/fra-2014-vaw-survey-main-resultsapr14_en.pdf

Giljohann, S. \& Bendix-Kaden, M. (2020). Polizeilicher Opferschutz bei Fällen bäuslicher Gewalt. Klinik für Kinder- und Jugendpsychiatrie/Psychotherapie, Universitätsklinikum Ulm. https:// haeuslichegewalt.elearning-gewaltschutz.de

Giljohann, S. \& Bendix-Kaden, M. (2020a). Polizeilicher Opferschutz bei Hocbrisikofällen bäuslicher Gewalt. Klinik für Kinder- und Jugendpsychiatrie/Psychotherapie, Universitätsklinikum Ulm. https:// haeuslichegewalt.elearning-gewaltschutz.de/

Grass, L. H., Mützel, E. \& Preuss, R. (2012). Medizinische Interventionen gegen Gewalt an Frauen II. Die Versorgung kann verbessert werden. Deutsches Äryteblatt, 109, 16.

Grass, H., Steffens, M. \& Hefer, B. (2014). Gewaltprävention - Schwierige Gratwanderung in der ärztlichen Praxis. Deutsches Ärzteblatt, 13, 450.

Hera, G. \& Szegő, D. (2020). Country Reports and Cross-National Comparison on the Risk Assessment Tools and Case Documentation used by Frontline Responders. https://improdova.eu/pdf/IMPRODOVA_D2.3_Risk_Assessment_Tools_and_Case_Doc umentation_of_Frontline_Responders.pdf?m $=1585673380 \&$

Hochschule für Politik München. (2020). Gewalt an Frauen und Kindern in Deutschland wäbrend COVID19-bedingten Ausgangsbeschränkungen: Zusammenfassung der Ergebnisse. https://www.kriminalpraevention.de/files/DFK/Praevention\%20haeuslicher\%20Gewalt/20 20_Studienergebnisse $\% 20$ Covid $\% 2019 \% 20$ HGEW.pdf

IMPRODOVA. (2020). Identifying gaps and bridges of intra- and inter-agency cooperation. https://improdova.eu/pdf/IMPRODOVA_D2.4_Gaps_and_Bridges_of_Intra_and_Interagency_Cooperation.pdf?m $=1585673383 \&$

Jungnitz, L., Lenz, H., Puchert, R., Puhe, H., \& Walter, W. (Eds.). (2007). Gewalt gegen Männer: Personale Gewaltwiderfahrnisse von Männern in Deutscbland. Opladen; Farmington Hills: Verlag Barbara Budrich. doi:10.2307/j.ctvdf049f

Novak, S. \& Galaway, B. (1983). Domestic Abuse Intervention Project Final Report. Duluth MN: Domestic Abuse Intervention Project.

Sacco, S. (2017). Häusliche Gewalt - Kostenstudie für Deutschland - Gewalt gegen Frauen in (ehemaligen) Partnerschaften. Trediton Verlag.

S.I.G.N.A.L. e.V. (2018). Umgang mit Gewalt in Paarberiehungen und mit sexueller Gewalt gegen Frauen. Leitlinien der WHO für Gesundheitsversorgung und Gesundheitspolitik. https:/ / www.signalintervention.de/sites/default/files/2020-04/WHO_Broschuere_4_9_18_web.pdf

S.I.G.N.A.L. e.V. (2020). Leitfäden für die Intervention in der Gesundheitsversorgung bei bäuslicher und sexualisierter Gewalt. https://signal-intervention.de/sites/default/files/202006/2020_06_10\%20Uebersicht_Leitfaeden_Gesundheit_final_0.pdf

Steffens, M. \& Janz, U. (2013). Arbeitshilfe für die ärztliche Praxis zum Vorgeben bei bäuslicher Gewalt. In: DGGG/Hess. Sozialministerium (HRSG). Ärztliches Praxishandbuch GEWALT (pp. 89_ 114). Verlag S. Kramarz.

Vogt, C. (2020). Interagency Cooperation. European Law Enforcement Research Bulletin, (19), 153-163. http://bulletin.cepol.europa.eu/index.php/bulletin/article/view/412

World Health Organization (WHO). (2013). Responding to intimate partner violence and sexual violence against women. WHO clinical and policy guidelines.

https://www.who.int/reproductivehealth/publications/violence/9789241548595/en/

\section{Legislative framework}

Council of Europe. (n.d.). Vollständige Liste der Verträge des Europarates. https://www.coe.int/de/web/conventions/full-list/-/conventions/rms/090000168008482e 
German Act on Protection against Violence (Gesetz zum zivilrechtlichen Schutz vor Gewalttaten und Nachstellungen/GewSchG). (2001). BGBl. I S. 3513. https://www.gesetze-iminternet.de/gewschg/BJNR351310001.html

German Civil Code (Bürgerliches Gesetzbuch/BGB). (2013). Federal Law Gazette I p. 3719. https://www.gesetze-im-internet.de/englisch_bgb/index.html

German Code of Criminal Procedure (Strafprozeßordnung/StPO). (2019). Federal Law Gazette I, p. 1066. https://www.gesetze-im-internet.de/englisch_stpo/index.html

German Criminal Code (Strafgesetztbuch/StGB). (1998). Federal Law Gazette I, p. 3322. https://www.gesetze-im-internet.de/englisch_stgb/index.html\#gl_p0776

German Social Code (Sozialgesetzbuch/SGB). (1990). BGBl. I S. 1163. https://www.gesetze-iminternet.de/sgb_8/

\section{Websites}

Baden-Württemberg.de. (n.d.). Pilotprojekt „Bekämpfung Häuslicher Gewalt" startet. https://www.badenwuerttemberg.de/de/service/presse/pressemitteilung/pid/pilotprojekt-bekaempfunghaeuslicher-gewalt-startet/

BIG. (n.d.). Webpage of the Berlin Initiative against Violence towards Women. https://www.bigberlin.info/node/270

BKA. (n.d.). Webpage of the Federal Criminal Police Office with the annual reports of the German Police Crime Statistics in English. [The specific reports on partner violence, however, only exist in German.] https://www.bka.de/EN/CurrentInformation/PoliceCrimeStatistics/policecrimestatistics_n ode.html

Charité. (n.d.). Physical violence. https://gewaltschutzambulanz.charite.de/en/affected/physical_violence/

DAIP. (n.d.). Webpage of the Domestic Abuse Intervention Programs. https://www.theduluthmodel.org/what-is-the-duluth-model/

Destatis. (n.d.). Webpage of the Federal Statistical Office with official data on the society, the economy, the environment and the state. https://www.destatis.de/EN/Themes/SocietyEnvironment/Population/Current-Population/_node.html

HAIP. (19.3.2021). Webpage of the Hanover Intervention Program against Domestic Violence. https://www.hannover.de/Leben-in-der-Region-Hannover/Verwaltungen-Kommunen/DieVerwaltung-der-Landeshauptstadt-Hannover/Gleichstellungsbeauf $\% \mathrm{C} 2 \%$ ADtragte-derLandeshauptstadt-Hannover/Wir-f $\%$ C3\%BCr-die-B $\% \mathrm{C} 3 \% \mathrm{BCrgerinnen-und-}$ B $\%$ C3\%BCrger/Hannoversches-Interventionsprogramm/\%C3\%9Cber-HAIP

Interdisciplinary Coordination Centre for Domestic Violence. (n.d.). Webpage of the "Interdisziplinäre Koordinierungsstelle Häusliche Gewalt für die Region Braunschweig". https://www.lab.niedersachsen.de/startseite/standorte/standort_braunschweig/interdiszipli nare_koordinierungsstelle_hausliche_gewalt/

S.I.G.N.A.L. (n.d.). Intervention im Gesundheitsbereich gegen bäusliche und sexualisierte Gewalt. https://www.signal-intervention.de/

Stalking KIT. (n.d.). Webpage of the Crisis-Intervention-Team Stalking and Domestic Violence in Bremen. http://www.stalking-kit.de/ 